\title{
EFFECT OF THE APPLICATION OF DIFFERENT WATER DEPTHS AND NITROGEN AND POTASSIUM DOSES ON QUALITY OF TANZANIA GRASS ${ }^{1}$
}

\author{
JAIR DA C. OLIVEIRA FILHO ${ }^{2}$, RUBENS A. DE OLIVEIRA ${ }^{3}$, \\ EDNALDO M. DE OLIVEIRA ${ }^{4}$, PAULO R. CECON ${ }^{5}$, CARLOS E. MARTINS ${ }^{6}$
}

\begin{abstract}
The objective of this study was to evaluate the effects of the application of different water depths and nitrogen and potassium doses in the quality of Tanzania grass, in the southern of the state of Tocantins. The experiment was conducted on strips of traditional sprinklers, and used, as treatments, a mixture of fertilizer combinations of $\mathrm{N}$ and $\mathrm{K}_{2} \mathrm{O}$ always in the ratio of $1 \mathrm{~N}: 0.8 \mathrm{~K}_{2} \mathrm{O}$. This study determined throughout the experiment: plant height $(\mathrm{PH})$, the crude protein $(\mathrm{CP})$ and neutral detergent fiber (NDF). The highest plant height obtained was $132.4 \mathrm{~cm}$, with a fertilizer dose of $691.71 \mathrm{~kg} \mathrm{ha}^{-1}$ in the proportion of N:0.8 K2 $\mathrm{O}$, in other words, $384.28 \mathrm{~kg} \mathrm{ha}^{-1}$ of $\mathrm{N}$ and $307.43 \mathrm{~kg} \mathrm{ha}^{-1}$ of $\mathrm{K}_{2} \mathrm{O}$, and water depth of $80 \%$ of the $\mathrm{ET}_{\mathrm{c}}$. The highest crude protein content was $12.2 \%$, with the fertilizer dose application of $700 \mathrm{~kg} \mathrm{ha}^{-1} \mathrm{yr}^{-1}$ in the proportion of $1 \mathrm{~N}$ to 0.8 of $\mathrm{K}_{2} \mathrm{O}$, in other words, $388.89 \mathrm{~kg} \mathrm{ha}^{-1}$ of $\mathrm{N}$ and $311.11 \mathrm{~kg} \mathrm{ha}^{-1}$ of $\mathrm{K}_{2} \mathrm{O}$ and absence of irrigation. The lowest level of neutral detergent fiber was $60.7 \%$ with the application of the smallest dose of fertilizer and highest water depth. It was concluded in this study that there was an increase in plant height by increasing the fertilizer dose and water depth. The crude protein content increased $5.4 \%$ in the dry season, by increasing the fertilizer dose and water depth. In the dry season, there was an increase of NDF content by $4.5 \%$ by increasing the application of fertilizer and water depth.
\end{abstract}

KEYWORDS: nitrogen fertilizer, irrigated pasture, Panicum maximum.

\section{EFEITOS DA APLICAÇÃO DE DIFERENTES LÂMINAS DE ÁGUA E DOSES DE NITROGÊNIO E POTÁSSIO NA QUALIDADE DO CAPIM-TANZÂNIA}

RESUMO: Teve-se como objetivo neste trabalho avaliar os efeitos da aplicação de diferentes lâminas de água e doses de nitrogênio e potássio na qualidade do capim-Tanzânia, no sul do Estado do Tocantins. O experimento foi conduzido em faixas com aspersão convencional e aplicou-se, como tratamentos, uma mistura de adubo com combinações de doses de $\mathrm{N}$ e $\mathrm{K}_{2} \mathrm{O}$ sempre na relação de $1 \mathrm{~N}: 0,8 \mathrm{~K}_{2} \mathrm{O}$. Para o estudo, determinaram-se ao longo do experimento: a altura de plantas ( $\mathrm{PH}$ ) e os teores de proteína bruta (PB) e de fibra em detergente neutro (FDN). A maior altura de plantas obtida foi de $132,4 \mathrm{~cm}$, com a dose de $691,71 \mathrm{~kg} \mathrm{ha}^{-1}$ do adubo na proporção de $1 \mathrm{~N}$ para 0,8 de $\mathrm{K}_{2} \mathrm{O}$, ou seja, $384,28 \mathrm{~kg} \mathrm{ha}^{-1}$ de $\mathrm{N}$ e $307,43 \mathrm{~kg} \mathrm{ha}^{-1}$ de $\mathrm{K}_{2} \mathrm{O}$ e lâmina de água de $80 \%$ da $\mathrm{ET}_{\mathrm{c}}$. O maior teor de proteína bruta foi de $12,2 \%$, com a aplicação da dose de $700 \mathrm{~kg} \mathrm{ha}^{-1}$ ano $^{-1}$ do adubo, na proporção de $1 \mathrm{~N}$ para 0,8 de $\mathrm{K}_{2} \mathrm{O}$, ou seja, 388,89 $\mathrm{kg} \mathrm{ha}^{-1}$ de $\mathrm{N}$ e $311,11 \mathrm{~kg} \mathrm{ha}^{-1}$ de $\mathrm{K}_{2} \mathrm{O}$ e ausência de irrigação. O menor teor de fibra em detergente neutro foi de $60,7 \%$ com a aplicação da menor dose de adubo e da maior lâmina de água. Concluiu-se, neste trabalho, que houve aumento na altura das plantas, com o aumento da dose do adubo e da lâmina de irrigação. O teor de proteína bruta aumentou 5,4\%, no período seco, com o incremento da dose de adubo e da lâmina de irrigação. No período seco, houve aumento do teor de FDN de 4,5\% com o incremento da aplicação da dose de adubo e da lâmina de água.

PALAVRAS-CHAVE: adubação nitrogenada, pastagem irrigada, Panicum maximum.

\footnotetext{
${ }^{1}$ Extraído da Tese de Doutorado do primeiro autor. Bolsista do Programa PQI da CAPES.

${ }^{2}$ Prof. Adjunto, Universidade Federal do Tocantins, UFT, Rua Badejós, Chácara 69/72, Caixa Postal 66, Zona Rural, Gurupi - TO, jair@uft.edu.br.

${ }^{3}$ Prof. Associado, Departamento de Engenharia Agrícola, UFV, Av. P.H.Rolfs s/n, Viçosa - MG, rubens@ufv.br.

${ }^{4}$ Departamento de Engenharia Agrícola, UFV, Av. P.H.Rolfs s/n, Viçosa - MG, ednaldoufv@ yahoo.com.br.

${ }^{5}$ Prof. Associado, Departamento de Estatística, UFV, Av. P.H.Rolfs, s/n, Viçosa - MG, cecon@ufv.br.

${ }^{6}$ Pesquisador, Dr., Embrapa Gado de Leite-CNPGL, R. Eugênio do Nascimento, 610, Juiz de Fora-MG, caeuma@ cnpgl.embrapa.br. Recebido pelo Conselho Editorial em: 5-10-2010

Aprovado pelo Conselho Editorial em: 15-2-2012
} 


\section{INTRODUCTION}

The exploration of the livestock activity under pasture intensive production, combined with favorable climatic conditions, has been a conditional factor of competitiveness and has provided to the farmer gains in scale production and increases in net revenue per unit of area.

The chains of meat and milk, with expressive participation in the national GDP and on the list of Brazilian exports, have the pastures as the main source of food for the cattle. Thus, the system of pasture production guarantees the supply of internal market with meat and milk at affordable prices and provides competitive advantage to Brazil in the international market of these two products. Accordingly to the Yearbook of Brazilian Livestock, ANUALPEC (2006), exports of bovine meat have had, in the last five years, an increase of $194 \%$ in exported amount and $227 \%$ in currency values, in U.S. dollars.

In livestock, the livestock production system on pasture is the largest determinant of competitiveness, but with a great challenge to be overcome: the maintenance of the supply of pasture, preferably of good quality (DRUMOND et al., 2006).

The management of soil fertility, fertilizer applications, knowledge of nutritional requirements, the effects of irrigation and climate are factors of great importance to the practice pasture management, which is reflected in higher or lower forage production and its nutritional quality (SILVA et al., 2005). Forage crops, such as Tanzania grass, has great economic importance for livestock, thus justifying the new research in the quality and quantity of forage production.

Regarding to soil fertility, nitrogen and potassium are nutrients that play an important role in the yield and quality of forage. The determination of irrigation frequency and amount of water to be applied in irrigation is critical to the success of the intensification of crop production (TAGLIAFERRE et al., 2010; SATO et al., 2007; BESKOW, 2008; SOUSA et al., 2010).

The interaction between nitrogen, potassium and water, to define the optimal doses of these factors in order to increase the supply of forage and its quality, is important, given the great diversity of soil and climate in Brazil. In this context, this study has as objective to evaluate the effects of applying different depths of water and nitrogen and potassium, the production quality of the Tanzania grass, in the southern of the state of Tocantins.

\section{MATERIAL AND METHODS}

The experiment was conducted at the Experimental Station of the Campus Universitário de Gurupi, Fundação Universidade do Tocantins, municipality of Gurupi, TO $\left(11^{\circ} 45^{\prime} \mathrm{S}, 4^{\circ} 03^{\prime} \mathrm{W}\right.$, altitude $287 \mathrm{~m}$ ). It was used the grass Panicum maximum cv. Tanzania.

Before the experiment, it was collect samples of soil, in the layer of $30 \mathrm{~cm}$ depth for chemical and physical analyzes. These soil analyzes were performed at the Laboratory of Analysis of Soils of the Soil Department at Federal University of Viçosa, in Brazil. Soil density was determined by volumetric ring method. The wilting point was determined using the method of Richards Extractor. The field capacity was determined by field method, according to the methodology described in EMBRAPA (1979).

An irrigation system with a close arrangement of the sprinklers in a single line, allowed an overlap of water jets, providing more rainfall along the lateral line and a decreasing perpendicular gradient to the pipeline. This system (Line Source Sprinkler System), developed for experimental purposes, allows the obtainment of different depths.

The experiment was conducted under a strip scheme along a line of sprinklers, using a completely randomized design with four replications. Each plot consisted of four combinations of $\mathrm{N}$ and $\mathrm{K}_{2} \mathrm{O}\left(\mathrm{D} 1=100+80, \mathrm{D} 2=300+240, \mathrm{D} 3=500+400, \mathrm{D} 4=700+560 \mathrm{~kg} \mathrm{ha}^{-1}\right)$, so that the combination of $\mathrm{N}$ and $\mathrm{K}_{2} \mathrm{O}$ keeps the ratio of $1 \mathrm{~N}$ to 0.8 of $\mathrm{K}_{2} \mathrm{O}$. The nitrogen source was urea, and the potassium source was potassium chloride. 
The experimental plots had $6 \mathrm{~m}$ wide and $18 \mathrm{~m}$ long, and plots with $5 \times 2 \mathrm{~m}$, arranged in strips representing the water depth applied proportionally to the crop evapotranspiration (L0 $=0$, $\mathrm{L} 1=18 \% \mathrm{ETc}, \mathrm{L} 2=45 \% \mathrm{ETc}, \mathrm{L} 3=77 \% \mathrm{ETc}, \mathrm{L} 4=100 \% \mathrm{ETc}$ and L5 $=120 \% \mathrm{ETc}$ ). Each subplot was divided in time, in two periods of the year.

The crop evapotranspiration was estimated in a daily basis based on soil moisture, and the same is considered equal to total depth required (Equation 1). The monitoring of soil moisture was carried out with tensiometers installed at $15 \mathrm{~cm}$ depth in D3L4 treatments. The calculation of the applied depth was carried out based on soil-water retention curve, according to the following equation:

$$
\mathrm{L}=\frac{(\mathrm{CC}-\mathrm{UA})}{10} \mathrm{D} \mathrm{Z} \frac{1}{\mathrm{Ea}}
$$

In which,

$\mathrm{L}$ - total depth required, mm;

CC - field capacity, \% weight;

UA - soil moisture at tension of approximately $40 \mathrm{kPa}, \%$ weight;

$\mathrm{D}$ - soil density, $\mathrm{g} \mathrm{cm}^{-3}$;

$\mathrm{Z}$ - effective rooting depth, $\mathrm{cm}$, and

Ea - water use efficiency, decimal.

Data were submitted to analysis of variance and regression. For the qualitative factor, the averages were compared by Tukey's test at 5\% probability. For quantitative factors, the models were chosen based on the significance of the regression coefficients, using the $t$ test at $5 \%$ probability. For the implementation of the statistical analyzes it was used the statistical program SAEG 9.1, developed by Federal University of Viçosa.

To study the influence of water depths and combinations of doses of $\mathrm{N}$ and $\mathrm{K}_{2} \mathrm{O}$ in Tanzania grass, in the two seasons of the year, it was determined throughout the experiment: plant height, the crude protein $(\mathrm{CP})$ and neutral detergent fiber (NDF).

Plant height was determined from the average of three measurements made at random subplots, from the soil surface to the tip of the apical leaves fully extended.

The systematic sampling of the grass was manually performed by simulating the pasture, so that the residue after grazing present around $15-20 \%$ of remaining green leaves.

The material collected, after drying in an oven, was called dry matter that can be consumed by the animal (DMBC), to differentiate the total dry matter which is usually used when it includes all the material produced, such as leaves, stems and senescent material, collected at one point by mechanical action. Unlike the action of grazing by the animal, which is selective, giving preference to the leaves and the pseudostem at the detriment of the consumption of stems and senescent material, this differential effect of sampled animals vs. mechanical interfere in crop physiology of plants, since the mechanical action at some point must extract greater number of apical buds, favoring the tillering, compared to the action of grazing. Therefore, the grazing simulation must retract better the animal relationship versus forage in the pasture production system.

All green mass collected was stored in plastic bags, properly identified and immediately weighed in a semi-analytical scale. Then a sub-sample was removed, weighed again and packaged in paper bags identified and placed to dry at $65^{\circ} \mathrm{C}$ in an oven with air circulation, for a period of 72 hours. The final weight was carried out one hour after the removal of material from the oven.

For bromatological analyzes, it was consisted a composite sample for each period studied (dry and rainy), using $2 \mathrm{~g}$ of each of the six samplings made. This was done for each of the four experimental replications. Evaluations of chemical composition were performed at the Laboratory of Forage Department of Animal Science, Federal University of Viçosa. 
The protein content was determined by Kjeldahl semimacro method, as described in AOAC (1990). The determination of neutral detergent fiber was performed accordingly to the method described by GOERING \& VAN SOEST (1970).

\section{RESULTS AND DISCUSSION}

In the dry season, plant height $(\mathrm{PH})$ of Tanzania grass varied quadratically with the doses of fertilizer (D) for each treatment at a proportion of 1 of $\mathrm{N}$ to $0.8 \mathrm{~K}_{2} \mathrm{O}(\mathrm{P}<0.01)$ and with the water depths $(\mathrm{W})$ applied by irrigation $(\mathrm{P}<0.01)$, accordingly to Equation 2 and Figure 1.

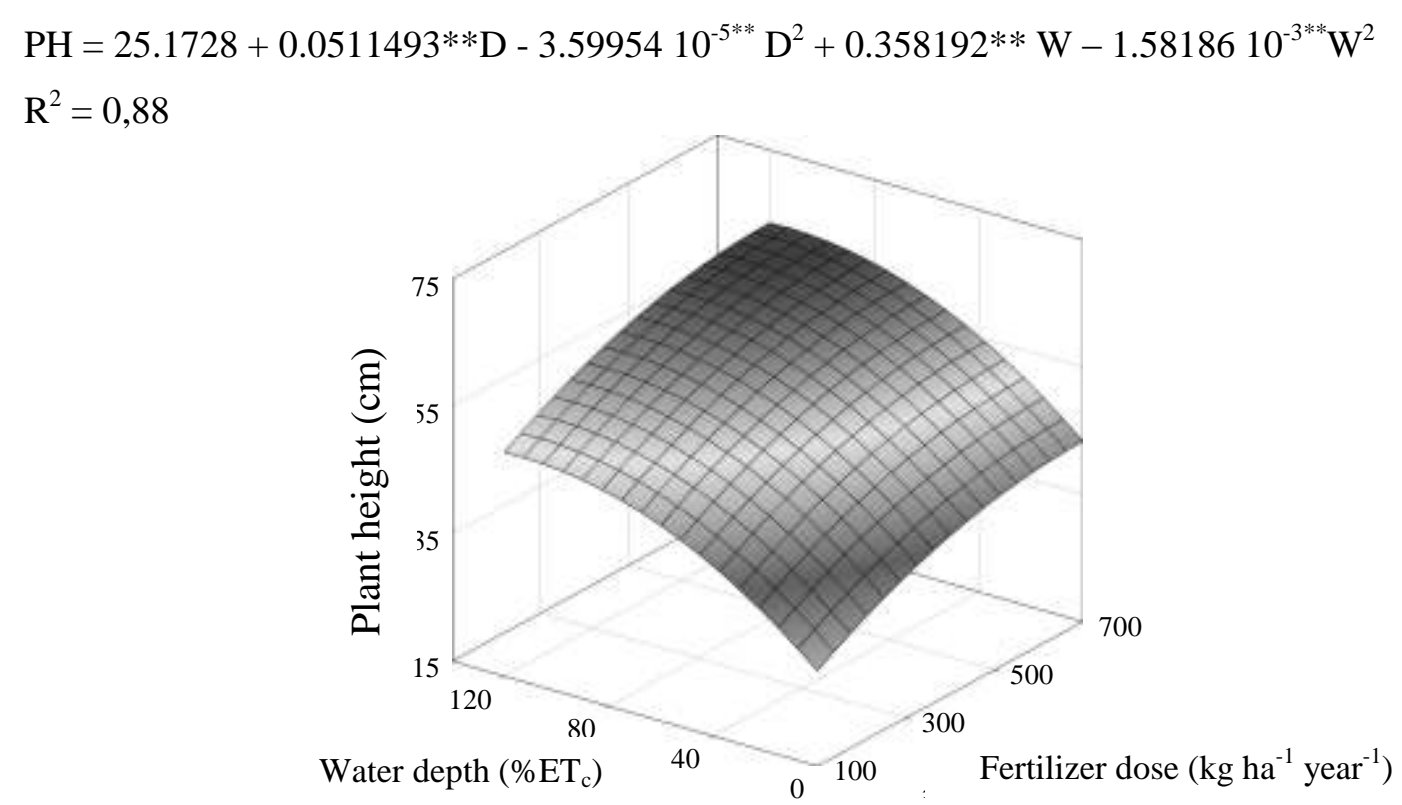

FIGURE 1. Estimate of plant heights of Tanzania grass, depending on the dose of fertilizer and water depth applied during the dry season.

The lowest plant height of Tanzania grass during the dry season was estimated at $29.9 \mathrm{~cm}$, with the application of the lowest dose of $100 \mathrm{~kg} \mathrm{ha}^{-1}$ year ${ }^{-1}$ of fertilizer in the proportion of $1 \mathrm{~N}$ to 0.8 of $\mathrm{K}_{2} \mathrm{O}$, in the absence of irrigation $\left(0 \% \mathrm{ET}_{\mathrm{c}}\right)$. The greatest height in the same period was $63.6 \mathrm{~cm}$, with the application of the dose of $700 \mathrm{~kg} \mathrm{ha}^{-1}$ year $^{-1}$ of fertilizer in the proportion of $1 \mathrm{~N}$ to $0.8 \mathrm{~K}_{2} \mathrm{O}$, and an estimated water depth of $113 \% \mathrm{ET}_{\mathrm{c}}$, obtaining an increase of $33.7 \mathrm{~cm}$ in height of the grass during the dry season.

Keeping the water depth constant, it was found that for every kilogram of fertilizer was added an average increase of $2.23 \times 10^{-2} \mathrm{~cm}$ in height of the Tanzania grass, or a total of $13.4 \mathrm{~cm}$ from the lowest to the highest dose applied.

Fixing the fertilizer doses, it was found that for every percentage unit of ETc until the maximum point of $113 \% \mathrm{ETc}$, there was an average increase in height of $0.2 \mathrm{~cm}$, or a total of $20.3 \mathrm{~cm}$.

During the rainy season, plant height $(\mathrm{PH})$ of the grass varied quadratically with doses of fertilizer (D) $(\mathrm{P}<0.01)$ and with the water depths (W) applied $(\mathrm{P}<0.10)$, accordingly to eq. $(2)$ and Figure 3. 


$$
\begin{aligned}
& \mathrm{PH}=52.0262=0.159978^{* *} \mathrm{D}-1.1563910^{-4 *} \mathrm{D}^{2}+0.25595^{* *} \mathrm{~W}-1.5973210^{-3 * *} \mathrm{~W}^{2} \\
& \mathrm{R}^{2}=0,90
\end{aligned}
$$

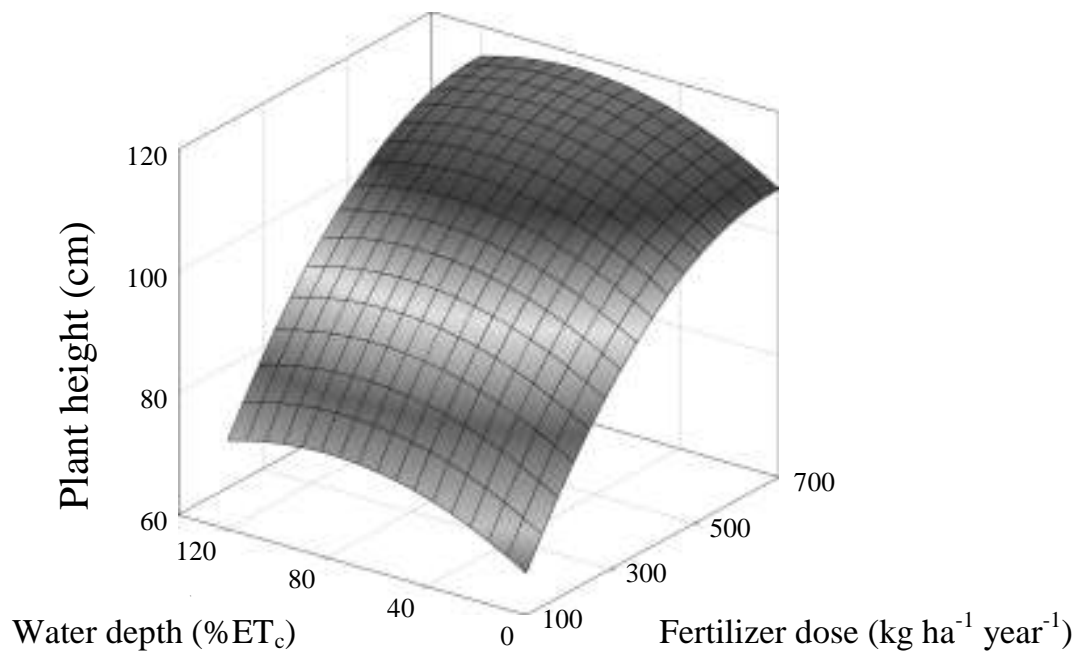

FIGURE 2. Estimate of plant heights of Tanzania grass, depending on the dose of fertilizer and water depth during the rainy season.

The lowest plant height of Tanzania grass during the rainy season was $66.9 \mathrm{~cm}$, with the application of the lowest dose of $100 \mathrm{~kg} \mathrm{ha}^{-1}$ year $^{-1}$ of fertilizer $\mathrm{N}$ in the proportion of $1 \mathrm{~N}$ to 0.8 $\mathrm{K}_{2} \mathrm{O}$, in the absence of irrigation ( $0 \%$ ETc). The greater height during this period was $132.4 \mathrm{~cm}$, with a dose of $691.71 \mathrm{~kg} \mathrm{ha}^{-1}$ of the fertilizer and a water depth of $80 \%$ ETc.

The maximum height reached of the Tanzania grass during the rainy season was nearly twice the maximum height achieved during the dry season, equals to $63.6 \mathrm{~cm}$

By fixing the doses of fertilizer, it was found that for every percentage unit of ETc applied until the inflection point, equals to $80 \% \mathrm{ETc}$, there was an increase in average height and $0.1 \mathrm{~cm}$ from the point of inflection to the depth $120 \%$ of ETc, an average reduction of $6.71 \times 10^{-2} \mathrm{~cm}$ in the plant height. By maintaining the water depth constant, it was observed that for each kilogram of fertilizer applied to the inflection point of maximum height corresponding to $691.71 \mathrm{~kg} \mathrm{ha}^{-1} \mathrm{year}^{-1}$ of the fertilizer in a proportion of $1 \mathrm{~N}$ to 0.8 of $\mathrm{K}_{2} \mathrm{O}$, there was an average growth of $6.84 \times 10^{-2} \mathrm{~cm}$ in Tanzania grass, a total of $40.5 \mathrm{~cm}$.

Table 1 presents the results of the average test between the heights of Tanzania grass for combinations of season, water depth and fertilizer dose, holding the comparison between the seasons, which is a qualitative variable. At doses of 100; 300; 500 and $700 \mathrm{~kg} \mathrm{ha}^{-1}$ year ${ }^{-1}$, the heights of the grass in the dry season differed from those obtained in the rainy season for all water depths studied. This difference may be explained by lower minimum temperatures during the dry season.

The average plant height during the rainy season $(98.4 \mathrm{~cm})$ was higher than the average height in the dry season $(51 \mathrm{~cm})$, showing once again that the temperature and photoperiod limited the growth, even in conditions of supply of fertilizer and appropriate depths. 
TABLE 1. Average values of height $(\mathrm{cm})$ of Tanzania grass in the combinations of time, water depth and dose of fertilizer.

\begin{tabular}{|c|c|c|c|c|}
\hline \multirow{3}{*}{$\begin{array}{r}\text { Water depth } \\
\left(\% \mathrm{ET}_{\mathrm{c}}\right)\end{array}$} & \multicolumn{4}{|c|}{ Fertilizer Dose $\left(\mathrm{kg} \mathrm{ha}^{-1}\right.$ year $\left.^{-1}\right)$} \\
\hline & \multicolumn{2}{|c|}{100} & \multicolumn{2}{|c|}{300} \\
\hline & $\mathrm{P} 1$ & $\mathrm{P} 2$ & $\mathrm{P} 1$ & $\mathrm{P} 2$ \\
\hline 0 & $37.04 \mathrm{~b}$ & $75.97 a$ & $38.25 b$ & $94.30 \mathrm{a}$ \\
\hline 18 & $36.91 b$ & $66.11 \mathrm{a}$ & $41.01 \mathrm{~b}$ & $90.20 \mathrm{a}$ \\
\hline 45 & $43.19 b$ & $77.43 \mathrm{a}$ & $49.55 b$ & $90.55 \mathrm{a}$ \\
\hline 77 & $47.78 b$ & $78.65 \mathrm{a}$ & $55.81 b$ & $99.93 \mathrm{a}$ \\
\hline 100 & $47.39 \mathrm{~b}$ & $72.64 a$ & $57.26 b$ & $102.57 \mathrm{a}$ \\
\hline \multirow[t]{3}{*}{120} & $45.17 \mathrm{~b}$ & $70.55 \mathrm{a}$ & $57.06 \mathrm{~b}$ & $99.42 \mathrm{a}$ \\
\hline & \multicolumn{2}{|c|}{500} & \multicolumn{2}{|c|}{700} \\
\hline & P1 & $\mathrm{P} 2$ & P1 & $\mathrm{P} 2$ \\
\hline 0 & $42.69 \mathrm{~b}$ & $108.54 \mathrm{a}$ & $38.19 b$ & $98.76 \mathrm{a}$ \\
\hline 18 & $43.96 b$ & $100.58 \mathrm{a}$ & $46.04 b$ & $108.00 \mathrm{a}$ \\
\hline 45 & $58.54 \mathrm{~b}$ & $113.33 \mathrm{a}$ & $58.12 b$ & $122.85 \mathrm{a}$ \\
\hline 77 & $57.60 \mathrm{~b}$ & $112.93 \mathrm{a}$ & $62.67 b$ & $125.54 \mathrm{a}$ \\
\hline 100 & $65.89 \mathrm{~b}$ & $111.80 \mathrm{a}$ & $62.05 b$ & $113.18 \mathrm{a}$ \\
\hline 120 & $61.04 \mathrm{~b}$ & $112.01 \mathrm{a}$ & $69.55 b$ & $115.46 a$ \\
\hline
\end{tabular}

* Averages followed by at least one same letter in rows for each water depth and fertilizer dose do not differ, $5 \%$ of probability by Turkey's test. P1 - dry season and P2 - rainy season.

During the dry period, the crude protein (CP) concentration of Tanzania grass varied quadratically with doses of fertilizer (D) in the proportion of $1 \mathrm{~N}$ to $0.8 \mathrm{~K}_{2} \mathrm{O}(\mathrm{P}<0.05)$ and with the water depths $(\mathrm{W})$ applied via irrigation $(\mathrm{P}<0.01)$ accordingly to Equation 4 and Figure 3.

$$
\begin{aligned}
& \mathrm{CP}=5.75631+0.0100297^{* *} \mathrm{D}-5.70 .10^{-6^{*}} \mathrm{D}^{2}+0.05^{* *} \mathrm{~W}-3.410^{-4^{* *}} \mathrm{~W}^{2} \\
& \mathrm{R}^{2}=0,90
\end{aligned}
$$

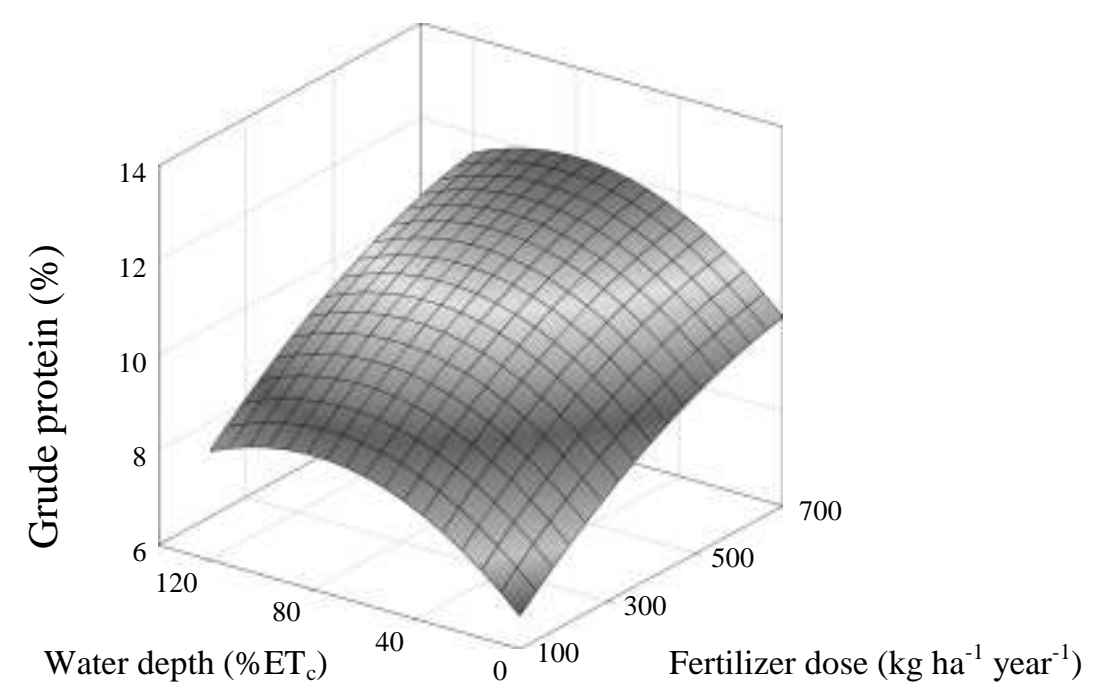

FIGURE 3. Estimate percentage of crude protein of l'anzania grass, depending on the dose of fertilizer and water depth during dry season.

The lowest crude protein content in the dry period was $6.7 \%$, with the use of the dose of $100 \mathrm{~kg} \mathrm{ha}^{-1}$ year $^{-1}$ of fertilizer in the proportion of $1 \mathrm{~N}$ to $0.8 \mathrm{~K}_{2} \mathrm{O}$, in the absence of irrigation $(0 \% \mathrm{ETc})$. The highest rate in this period was $12.1 \%$, with the application of the fertilizer dose of 
$700 \mathrm{~kg} \mathrm{ha}^{-1}$ and estimated maximum water depth of $80 \%$ ETc, obtaining a $5.4 \%$ increase in crude protein during dry season.

By setting the dose of the fertilizer, it was found that the increase of every percentage unit of ETc, until the inflection point of $80 \%$ ETc, resulted in an average increase of $2.65 \times 10^{-2} \%$ in CP; from that point until the depth of $120 \%$ of ETc, an average reduction of $1.31 \times 10^{-2} \%$ occurred. With a constant water depth, it was found that each kilogram of fertilizer applied caused an increase average of $1.01 \times 10^{-2} \% \mathrm{CP}$ of Tanzania grass, with an accumulated total of $6.1 \%$ between the lowest and highest applied dose during dry season.

In the rainy season, the crude protein varied linearly with doses of fertilizer $(\mathrm{P}<0.01)$ and water depths applied $(\mathrm{P}<0.01)$, accordingly to Equation 5 and Figure 4.

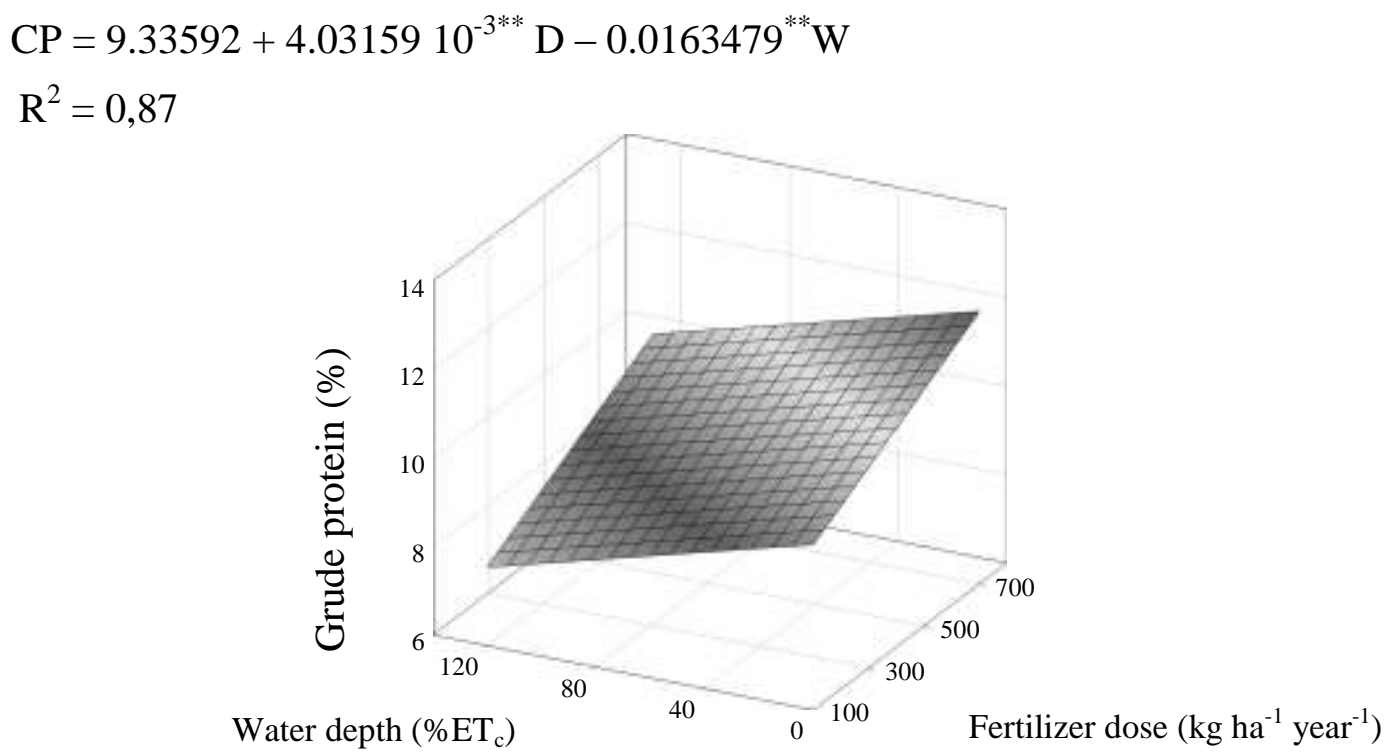

FIGURE 4. Estimate percentage of crude protein of Tanzania grass, depending on the dose of fertilizer and water depth during the rainy season.

The lowest crude protein content in the rainy season was $7.8 \%$, with the use of the $100 \mathrm{~kg} \mathrm{ha}^{-1}$ year $^{-1}$ of fertilizer in the proportion of $1 \mathrm{~N}$ to 0.8 of $\mathrm{K}_{2} \mathrm{O}$ and water depth applied of $120 \%$ ETc. The highest rate in this period was $12.2 \%$, with the application of the dose of $700 \mathrm{~kg} \mathrm{ha}^{-1}$ year $^{-1}$ of fertilizer and no irrigation, $0 \%$ ETc.

When the fertilizer dose was constant, it was observed a decrease of $2 \%$ of crude protein, from the smallest to the largest depth applied. In turn, when the depth was kept constant, there was an increase of $2.4 \%$ crude protein in the Tanzania grass, for the variation of the fertilizer dose from 100 to $700 \mathrm{~kg} \mathrm{ha}^{-1}$ year $^{-1}$ during the rainy season.

Table 2 presents the average levels of crude protein from Tanzania grass for the combinations of water depth, fertilizer dose and season. At a fertilizer dose of $100 \mathrm{~kg} \mathrm{ha}^{-1}$ year $^{-1}$, the crude protein in the dry period differed from the values obtained in the rainy season only at irrigation levels of 0 and $18 \%$ of ETc. At doses of 500 and $700 \mathrm{~kg} \mathrm{ha}^{-1} \mathrm{year}^{-1}$ of fertilizer in the proportion of $1 \mathrm{~N}$ to $0.8 \mathrm{~K}_{2} \mathrm{O}$, the crude protein levels during the dry season differed from the levels in the rainy season in all water depths applied. At a dose of $300 \mathrm{~kg} \mathrm{ha}^{-1} \mathrm{year}^{-1}$, the levels of crude protein in the dry period did not differ only regarding the water depth of $77 \%$ of ETc in the rainy season, and in the other depths there was no statistical difference between the two seasons.

It was also noted in Table 2 that the average contents of crude protein in the rainy season were higher than those obtained in the dry season with irrigation absence and in the applied depth $18 \%$ of ETc, in all applied fertilizer doses. This can be explained by the accumulation of fertilizer applied in coverage during the dry season, causing residual effect on soil in the rainy season. 
TABLE 2. Average values of crude protein (\%) of Tanzania grass in the combinations of water depth, fertilizer dose and season.

\begin{tabular}{|c|c|c|c|c|}
\hline \multirow{3}{*}{$\begin{array}{l}\text { Water depth } \\
\left(\% \mathrm{ET}_{\mathrm{c}}\right)\end{array}$} & \multicolumn{4}{|c|}{ Fertilizer Dose $\left(\mathrm{kg} \mathrm{ha}^{-1}\right.$ year $\left.^{-1}\right)$} \\
\hline & \multicolumn{2}{|c|}{100} & \multicolumn{2}{|c|}{300} \\
\hline & $\mathrm{P} 1$ & $\mathrm{P} 2$ & $\mathrm{P} 1$ & $\mathrm{P} 2$ \\
\hline 0 & $6.96 b$ & $9.75 a$ & $8.23 b$ & $9.86 a$ \\
\hline 18 & $7.83 b$ & $9.06 \mathrm{a}$ & $9.32 b$ & $10.55 \mathrm{a}$ \\
\hline 45 & $8.57 \mathrm{a}$ & $8.53 \mathrm{a}$ & $10.19 \mathrm{a}$ & $9.49 b$ \\
\hline 77 & $8.25 \mathrm{a}$ & $8.56 a$ & $9.78 \mathrm{a}$ & $9.33 \mathrm{a}$ \\
\hline 100 & $8.32 \mathrm{a}$ & $8.25 \mathrm{a}$ & $9.94 a$ & $9.18 b$ \\
\hline \multirow[t]{3}{*}{120} & $8.56 \mathrm{a}$ & $8.18 \mathrm{a}$ & $10.32 \mathrm{a}$ & $9.02 b$ \\
\hline & \multicolumn{2}{|c|}{500} & \multicolumn{2}{|c|}{700} \\
\hline & $\mathrm{P} 1$ & $\mathrm{P} 2$ & $\mathrm{P} 1$ & $\mathrm{P} 2$ \\
\hline 0 & $8.84 b$ & $11.24 \mathrm{a}$ & $8.98 b$ & $13.21 \mathrm{a}$ \\
\hline 18 & $10.47 b$ & $11.72 \mathrm{a}$ & $11.34 \mathrm{~b}$ & $12.14 \mathrm{a}$ \\
\hline 45 & $11.57 \mathrm{a}$ & $10.46 b$ & $12.20 \mathrm{a}$ & $11.17 \mathrm{~b}$ \\
\hline 77 & $11.43 \mathrm{a}$ & $9.92 b$ & $12.24 \mathrm{a}$ & $10.18 b$ \\
\hline 100 & $11.08 \mathrm{a}$ & $9.79 b$ & $11.26 \mathrm{a}$ & $10.17 \mathrm{~b}$ \\
\hline 120 & $10.97 \mathrm{a}$ & $9.61 \mathrm{~b}$ & $12.16 \mathrm{a}$ & $9.82 b$ \\
\hline
\end{tabular}

* Averages followed by at least one same letter in rows for each water depth and fertilizer dose do not differ, $5 \%$ of probability by Turkey's test. P1 - dry season and P2 - rainy season.

ALENCAR et al. (2009), in an experiment conducted in Governador Valadares, Minas Gerais, with several tropical forage grasses, in different irrigation water depths, obtained average values of 10.05 and $9.54 \%$ of $\mathrm{CP}$ in dry and rainy seasons, respectively, very close to the values found in this experiment, of 9.9 and $10 \%$ in both periods, respectively.

The content of neutral detergent fiber (NDF) of Tanzania grass during the dry season varied linearly with fertilizer doses $(\mathrm{P}<0.01)$ and the water depth applied $(\mathrm{P}<0.01)$, accordingly with eq.(6) and Figure 5.

$$
\begin{aligned}
& \mathrm{NDF}=63.46+2.5210^{-3} \mathrm{D}-0.03 \mathrm{~W} \\
& \mathrm{R}^{2}=0,59
\end{aligned}
$$

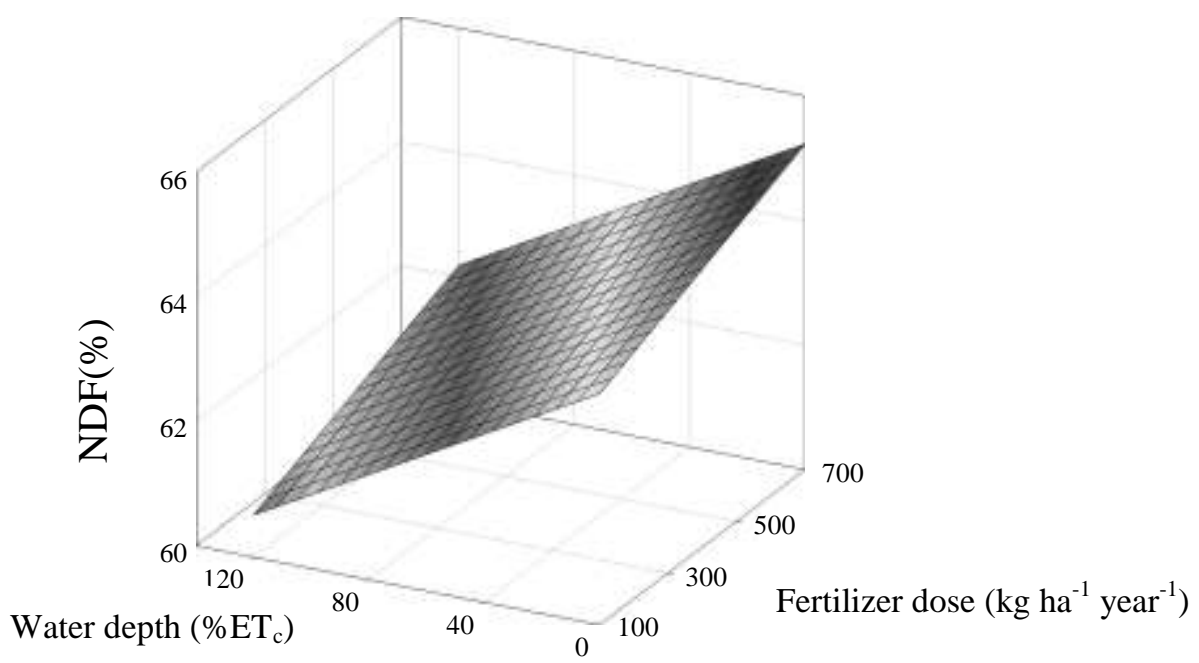

FIGURE 5. Estimate neutral detergent fiber of Tanzania grass, depending on the fertilizer dose and water depth during the dry season. 
The lower NDF content was $60.7 \%$ with the application of the lowest dose of fertilizer and increased water depth. However, the higher content was $65.2 \%$ with the highest level of fertilizer and in the absence of irrigation.

By fixing the dose of fertilizer at $1 \mathrm{~N}$ to $0.8 \mathrm{~K}_{2} \mathrm{O}$, it was obtained a total reduction of $3.0 \%$ in $\mathrm{NDF}$, demonstrating in this way, the effect of irrigation on improving the quality of forage during dry season.

By maintaining the water level constant during this period, there was an overall increase of $1.5 \%$ in total of NDF, or a rate of $2.52 \times 10^{-3} \%$ in the NDF level per kilogram of the added fertilizer.

In the rainy season there was no effect of the sources of variation regarding the dose of fertilizer and water depth, in the content of neutral detergent fiber. This allowed them to adopt the average value of NDF in this period, equal to $64.0 \%$.

Table 3 presents the average levels of neutral detergent fiber from Tanzania grass in combinations of water depth, fertilizer dose and season. Comparing the mean values of NDF in various doses and irrigation study, it was noted that the significant differences observed between the levels obtained in the dry and rainy season occur randomly. It was expected predominance of higher values of NDF in the rainy season when conditions are more favorable for the plant growth, providing in this way, early aging of the grass compared to the dry season.

ALENCAR et al. (2009) obtained NDF of 66.73 and $68.36 \%$ in the dry and rainy seasons, respectively, higher than the average found in this experiment, 62.9 and $64.0 \%$ of NDF, in the respective seasons. This improvement in forage quality observed in this study may be associated with application of potassium fertilizer topdressing.

TABLE 3. Average values of neutral detergent fiber (\%) of Tanzania grass in the interaction of water depth $\mathrm{x}$ fertilizer dose $\mathrm{x}$ season.

\begin{tabular}{cccccc}
\hline \multirow{2}{*}{$\begin{array}{c}\text { Water Depth } \\
\left(\% \mathrm{ET}_{\mathrm{c}}\right)\end{array}$} & \multicolumn{5}{c}{ Fertilizer Dose $\left(\mathrm{kg} \mathrm{ha}^{-1} \mathrm{year}^{-1}\right)$} \\
\cline { 2 - 3 } \cline { 5 - 5 } & $\mathrm{P} 1$ & $\mathrm{P} 2$ & $\mathrm{P} 1$ & 300 \\
\hline 0 & $63.43 \mathrm{~b}$ & $64.95 \mathrm{a}$ & & $64.74 \mathrm{a}$ & $\mathrm{P} 2$ \\
18 & $63.29 \mathrm{a}$ & $64.17 \mathrm{a}$ & & $65.05 \mathrm{a}$ & $64.00 \mathrm{a}$ \\
45 & $61.24 \mathrm{~b}$ & $65.01 \mathrm{a}$ & & $62.41 \mathrm{~b}$ & $64.48 \mathrm{a}$ \\
77 & $61.29 \mathrm{~b}$ & $64.58 \mathrm{a}$ & & $61.29 \mathrm{~b}$ & $65.03 \mathrm{a}$ \\
100 & $62.68 \mathrm{~b}$ & $64.37 \mathrm{a}$ & & $61.66 \mathrm{~b}$ & $63.98 \mathrm{a}$ \\
120 & $62.16 \mathrm{a}$ & $62.75 \mathrm{a}$ & $61.34 \mathrm{~b}$ & $62.95 \mathrm{a}$ \\
\hline
\end{tabular}

\begin{tabular}{ccccccc}
\hline & \multicolumn{3}{c}{500} & & \multicolumn{2}{c}{700} \\
\cline { 2 - 3 } \cline { 5 - 6 } & P1 & P2 & & P1 & P2 \\
\hline 0 & $64.54 \mathrm{a}$ & $63.07 \mathrm{~b}$ & & $66.69 \mathrm{a}$ & $62.76 \mathrm{~b}$ \\
18 & $63.87 \mathrm{a}$ & & $62.93 \mathrm{a}$ & & $65.89 \mathrm{a}$ & $64.43 \mathrm{a}$ \\
45 & $62.50 \mathrm{a}$ & $63.03 \mathrm{a}$ & & $64.26 \mathrm{a}$ & $64.49 \mathrm{a}$ \\
77 & $60.87 \mathrm{~b}$ & & $63.89 \mathrm{a}$ & & $61.60 \mathrm{~b}$ & $65.39 \mathrm{a}$ \\
100 & $62.26 \mathrm{~b}$ & $63.91 \mathrm{a}$ & & $63.46 \mathrm{a}$ & $64.42 \mathrm{a}$ \\
120 & $61.88 \mathrm{~b}$ & $64.01 \mathrm{a}$ & & $62.48 \mathrm{a}$ & $63.65 \mathrm{a}$ \\
\hline
\end{tabular}

* Averages followed by at least one same letter in rows for each water depth and fertilizer dose do not differ, $5 \%$ of probability by Turkey's test. P1 - dry season and P2 - rainy season.

\section{CONCLUSIONS}

Both in the dry season and the rainy season, there were an increase of approximately $100 \%$ in plant height by increasing the fertilizer dose and irrigation. 
The lower heights of Tanzania grass plants were obtained by applying the lowest dose of $100 \mathrm{~kg} \mathrm{ha}^{-1}$ fertilizer at $1 \mathrm{~N}$ to 0.8 of $\mathrm{K}_{2} \mathrm{O}$ in the absence of irrigation $(0 \% \mathrm{ETc})$.

The crude protein level increased $5.4 \%$ in the dry season, by increasing the fertilizer dose and irrigation. During the rainy season, it was not possible to identify the effect of variations in fertilization and irrigation regarding this variable.

In the dry period, there was an increase in the NDF concentration of $4.5 \%$ by increasing the application of fertilizer dose and water depth. There was no effect of variation sources, dose and water depth in the content of neutral detergent fiber during the rainy season regarding this variable.

\section{REFERENCES}

ALENCAR, C.A.B.; CÓSER, A.C.; MARTINS, C.E.; OLIVEIRA, R.A.; CECON, P.R.; LEAL, B.G.; FIGUEIREDO, J.L.A.; CUNHA, F.F. Doses de nitrogênio e estações do ano afetando a composição bromatológica e digestibilidade de capins cultivados sob pastejo. Revista Ceres, Viçosa-MG, v.56, n.5, p.640-647, 2009.

ANUALPEC. ANUÁRIO DA PECUÁRIA BRASILEIRA. São Paulo: Instituto FNP, 2003 e 2006. Disponível em: <http://www.agrafnp.com.br/prodserv/estatisticas/index.php>. Acesso em: 11 jun. 2007.

AOAC. ASSOCIATION OF OFFICIAL ANALYTICAL CHEMISTS. Official methods of analysis. $15^{\text {th }}$ ed. Arlington, 1990. v.1, p.72-74.

BESKOW, S.; COLOMBO, A.; RIBEIRO, M.S.; FERREIRA, L.S.; ROSSI, R. Simulação das perdas de água por evaporação e arraste, no aspersor NY-7 (4,6 mm x 4,0 mm), em sistemas de aspersão convencional. Engenharia Agrícola, Jaboticabal, v.28, n.3, p.427-437, 2008.

DRUMOND, L.C.D.; ZANINI, J.R.; AGUIAR, A. de P.A.; RODRIGUES, G.P.; FERNANDES, A.L.T. Produção de matéria seca em pastagem de tifton 85 irrigada, com diferentes doses de dejeto líquido de suíno. Engenharia Agrícola, Jaboticabal, v.26, n.2, p. 426-433, 2006.

EMBRAPA. EMPRESA BRASILEIRA DE PESQUISA AGROPECUÁRIA. Manual de métodos de análise de solo. Rio de Janeiro: Serviço Nacional de Levantamento e Conservação de Solos, 1979. $247 \mathrm{p}$.

GOERING, H.K.; VAN SOEST, P.J. Forage fiber analysis (Apparatus, reagents, procedures and some applications). United States Department of Agriculture, 1970. 20 p. (Agr. Handboock, 379).

SATO, F.A.; SILVA, A.M.; COELHO, G.; SILVA, A.C.; CARVALHO, L.G. Coeficiente de cultura $(\mathrm{kc})$ do cafeeiro (Coffea arabica L.) no período de outono-inverno na região de Lavras MG. Engenharia Agrícola, Jaboticabal, v.27, n.2, p.383-391, 2007.

SILVA, L.D.B.; FOLEGATTI, M.V.; VILLA NOVA, N.A. Evapotranspiração do capim Tanzânia obtida pelo método de razão de Bowen e lisímetro de pesagem. Engenharia Agrícola, Jaboticabal, v.25, n.3, p.705-712, 2005.

SOUSA, A.E.C.; BEZERRA, F.M.L.; SOUSA, C.H.C.; SANTOS, F.S.S. Produtividade do meloeiro sob lâmina de irrigação e adubação potássica. Engenharia Agrícola, Jaboticabal, v.30, n.2, p.271-278, 2010.

TAGLIAFERRE, C.; OLIVEIRA, R.A.; OLIVEIRA, E.M.; BAPTESTINI, J.C.B.; SANTOS, L.C. Desempenho do irrigâmetro no manejo da água de irrigação na cultura do feijoeiro. Revista Caatinga, Mossoró, v.23, n.3, p.110-117, 2010. 